\title{
Residual effects of corncob biochar on tropical degraded soil in central Uganda
}

\author{
Samuel Obeng Apori ${ }^{*} \mathbb{D}$, John Byalebeka² and Gideon Kalii Muli
}

\begin{abstract}
Background: The residual effects of biochar are yet to receive adequate research attention in Sub-Saharan Africa despite the assumption that the positive effect of biochar may last longer on degraded tropical soil. Hence a field experiment was conducted to assess the residual effects of biochar, farmyard compost and NPK fertilizer applications on a Ferralsol in central Uganda. The field used for the study was previously used to conduct experiments for two seasons to assess the contribution of corncob biochar to the chemical properties of this highly degraded tropical soil.

Result: The co-applied biochar with compost and NPK fertilizer significantly $(p<0.05)$ increased some soil chemical properties such as soil pH, available phosphorus, soil organic carbon, and potassium than the control. The co-applied biochar with compost also significantly $(p<0.05)$ increased the soil $\mathrm{pH}$ and effective cation exchange capacity compared to the solely applied compost and NPK fertilizer. Collard plant height, canopy, stem girth, number of leaves, leaf length, and total biomass were significantly $(p<0.05)$ higher in the biochar amended soil than the unamended soil.

Conclusion: It was concluded that the addition of biochar with compost and NPK fertilizer had a significant residual effect on degraded tropical soils than solely applied NPK and compost.
\end{abstract}

Keywords: Biochar, Residual effects, Soil quality, Nutrient constituents

\section{Introduction}

The long-term cultivation of most tropical soils has resulted in severe depletion of organic carbon, the disintegration of soil aggregate stability, serious soil erosion and deterioration of soil fertility (Ding et al. 2016). As a measure to sustainably restore and manage these degraded tropical soils, biochar has been used to improve their physico-chemical properties (El-Naggar et al. 2019). Biochar is a carbonaceous material produced from the by-product of feedstock pyrolysis in a limited or no oxygen condition (Verheijen et al. 2010; Sohi et al. 2010). The nutrients content of biochar is dependent on the pyrolysis time, feedstock type and pyrolysis temperature (Ronsse et al. 2013; Al-Wabel et al. 2018). Some of the physical properties of the soil that have been reported to improve

\footnotetext{
*Correspondence: apori.samuel@umu.ac.ug

${ }^{1}$ African Center of Excellence in Agroecology and Livelihood System,

Faculty of Agriculture, Uganda, Martyrs University, Kampala, Uganda

Full list of author information is available at the end of the article
}

after the application of biochar are bulk density, porosity, soil aggregation, soil structure, infiltration rate and water retention (Blanco-Canqui, 2017). Laird et al. (2010), concluded that applying biochar to the soil can lead to retention of $15 \%$ more soil moisture compared to soils without biochar. Chemical and biological characteristics of the soil that have been reported to improve after biochar application are microbial activities and enzyme, nitrogen and phosphorus recycling, soil acidity reduction, cation exchange capacity and electrical conductivity ( $\mathrm{Xu}$ et al. 2014; Lehman et al. 2011; Nguyen et al. 2018).

However, the sole application of biochar cannot provide adequate amounts of nutrients for proper plant growth nor can the sole application of convectional fertilizer or the sole application of organic resources (Glaser and Birk 2012). Hence many studies have concluded that combining biochar with organic or inorganic resources is very effective for reclamation of degraded soil (SánchezMonedero et al. 2019; Liu et al. 2012; Tang et al. 2020). Co-applying biochar with organic resources causes the
Springer Open (c) The Author(s) 2021. Open Access This article is licensed under a Creative Commons Attribution 4.0 International License, which permits use, sharing, adaptation, distribution and reproduction in any medium or format, as long as you give appropriate credit to the original author(s) and the source, provide a link to the Creative Commons licence, and indicate if changes were made. The images or other third party material in this article are included in the article's Creative Commons licence, unless indicated otherwise in a credit line to the material. If material is not included in the article's Creative Commons licence and your intended use is not permitted by statutory regulation or exceeds the permitted use, you will need to obtain permission directly from the copyright holder. To view a copy of this licence, visit http://creativecommons.org/licenses/by/4.0/. 
slow release of nutrient to the soil environment, resulting in the decrease of nutrient leaching (Mensah and Frimpong 2018) while co-applying biochar with conventional fertilizer decreased the amount of biochar needed to improve the degraded soil, decreased soil acidity, enhanced the soil physical environment to boost the inorganic fertilizer retention resulting in high nutrients use efficiency (Nielsen et al. 2018).

Many studies have focused on the direct effect of coapplying biochar with organic resources and conventional fertilizers although there is an assumption that the positive effect of co-applied biochar with organic and inorganic resources may last longer (Wisnubroto et al. 2017). As a result of high nutrient absorption capacity of the biochar, there is a potential that applying biochar with inorganic and organic resources will cause a slow release of nutrient to the soil environment on a long-term basis. Hence the main objective of this study was to assess the residual potential of co-applied biochar with organic resources and convectional fertilizer for the restoration of tropical degraded soil. The study is underpinned by the hypotheses that the residual effects of co-applied biochar with compost and/NPK will improve degraded soil more than the residual effect of the compost and the NPK.

\section{Materials and methods Study setup}

The study was conducted on a field that was previously used to examine the direct contribution of applied corncob biochar in combination with compost and NPK fertilizer on highly degraded soil at Uganda Martyrs University Research Farm in Central Uganda in 2020. Uganda Martyrs University Research Farm lies alongside the equator line at Latitude $0^{\circ} 00^{\prime} 17^{\prime} \mathrm{N}$ and Longitude $32^{\circ} 00^{\prime} 57^{\prime} \mathrm{E}$. The site receives a bimodal rainfall with a mean annual rainfall of $1100 \mathrm{~mm}$ and with minimum annual temperature ranging between $20-23{ }^{\circ} \mathrm{C}$ and the maximum between $23-36^{\circ} \mathrm{C}$, respectively. The soil in the experimental field is a haplic Ferralsol with a sandy clay loam texture. Detailed physicochemical properties of the soil used are presented in Table 1.

Table 1 shows the results of the laboratory analysis of the experimental site soil, corncob biochar and farmyard manure compost used in the previous field study. These results show that the experimental site soil is sandy clay loam, quite acidic (pH: 5.1 ) and generally very poor in most plant nutrients when compared to the corncob biochar and farmyard manure compost.

The previous experiment adopted a Complete Randomized Block (CRB) design with nine (9) treatments, namely control, two rates of biochar, one level of compost, one level of NPK, and four levels of mixtures of biochar, compost and NPK. Four blocks of the nine plots
Table 1 Physico-chemical properties of the field soil, corn cob biochar and farmyard compost used in the previous experiment

\begin{tabular}{|c|c|c|c|}
\hline Parameters & $\begin{array}{l}\text { Corn } \\
\text { cob } \\
\text { biochar }\end{array}$ & $\begin{array}{l}\text { Farmyard } \\
\text { manure } \\
\text { compost }\end{array}$ & $\begin{array}{l}\text { Experimental } \\
\text { soil }\end{array}$ \\
\hline $\mathrm{pH}-\mathrm{H}_{2} \mathrm{O}$ & 6.9 & 6.12 & 5.1 \\
\hline Total organic carbon (\%) & 73 & 68.2 & 0.33 \\
\hline Total nitrogen (\%) & 0.75 & 1.50 & 0.29 \\
\hline $\begin{array}{l}\text { Available phosphophorus (mg/ } \\
\text { kg) }\end{array}$ & 6.57 & 7.13 & 5.21 \\
\hline Potassium $(\mathrm{cmol} / \mathrm{kg})$ & 7.9 & 4.36 & 0.43 \\
\hline Calcium (cmol/kg) & 1.1 & 0.71 & 0.4 \\
\hline Sodium (cmol/kg) & 0.9 & 1.32 & 0.9 \\
\hline Magnesium (cmol/kg) & 1.4 & 3.41 & 2.1 \\
\hline $\begin{array}{l}\text { Cation exchange capacitity } \\
(\mathrm{cmol} / \mathrm{kg})\end{array}$ & 1.7 & 0.98 & 4.32 \\
\hline Percent sand & NA & NA & 64 \\
\hline Percent clay & NA & NA & 30 \\
\hline Percent silt & NA & NA & 6 \\
\hline
\end{tabular}

NA not applicable

were made with $0.5 \mathrm{~m}$ and $1.0 \mathrm{~m}$ gaps between plots and blocks, respectively. The rate of the farmyard manure compost used was adopted and modified from Van der Wurff AW et al. (2016) who concluded that the application rate of compost ranging from $6 \mathrm{t} / \mathrm{ha}$ to $10 \mathrm{t} / \mathrm{ha}$ adequate to provide soil nutrient to horticulture crops when applied to the soil. The recommendation rate of NPK $(200 \mathrm{~kg} / \mathrm{ha})$ was adopted and modified from Mclaurin and Reeves (2009) whiles the treatment combination used the integrated plant nutrition system strategy (IPNS) i.e. combining half of the sole application of the biochar with half of the sole application of the farmyard compost and NPK (Choudhary et al. 2013). IPNS promotes the minimum effective rate of adequate and balanced quantities of applying inorganic and organic resources to results in high soil nutrients availability and crop productivity (Selim 2020). The biochar used was produced from a modified oil barrel having a similar function as the Elsa stove. Corncob feedstock was selected for biochar production and pyrolysis at a temperature between $450^{\circ} \mathrm{C}$. A detailed description of the treatments used in the previous experiment is presented in Table 2 while the characteristics of the biochar and the compost are presented in Table 1.

In this current study, the previously studied plots and the treatments were maintained to evaluate the residual effect of biochar, farmyard yard compost and/ NPK on tropical degraded soil conducted in September 2020 using Brassica oleracea var. viridis (Collard plant) as a test crop. The selection of the collard plant was based on its high consumption in Eastern Africa (Neugart et al. 
2017) and their low nutrient composition in their leaves as a result of the poor fertility of the degraded soil (Antonious et al. 2014). Hence we aim to improve the nutrient composition of the collard plant by improving the degraded soil through biochar technology. The collard plant seed was purchase from the seed shop in Kampala, Uganda. A thirty days old seedling of the collard plants was transplanted per plot using a planting distance of $0.5 \mathrm{~m} \times 0.5 \mathrm{~m}$. In all, sixteen seedlings were transplanted per plot. Weeding was done every three weeks using a hoe and Supplementary irrigation was supplied every 2 days using watering cans in the event of no rainfall.

From Table 3, the carbonization time for the production of the corncob using the Elsa barrel was 49 min. A weight of $15.5 \mathrm{~kg}$ of the corncob feedstock gave a biochar output of $6.75 \mathrm{~kg}$ and a lower efficiency of $30.67 \%$. The volatile matter recorded was $9.24 \%$ whiles Ash and the fixed carbon recorded a value of $37.96 \%$ and $40.41 \%$, respectively. The low efficiency recorded by the Elsa barrel was due to the uncontrolled burning of biochar with open air. Volatile matter recorded was low for the carbonization methods compare with the Ash and fixed carbon content of the biochar. According to Yuan et al. (2011), volatile matter of biochar decreases with regard to high temperature. The ash content recorded was very high due to the increased exposure to oxygen supply because whenever the amount of smoke increased, the cover was opened to allow more airflow into the barrel. Biochar with high ash content will have lower fixed carbon less than $50 \%$, contributing to the inhibition of aromatic carbon structures (Enders et al. 2012).
Soil sampling and physicochemical analysis of the soil The soil samples were collected from each plot at a depth of $0-30 \mathrm{~cm}$ using the auger after harvest. The samples were air-dried at room temperature in the drying room before sending it to the laboratory. The samples were crushed with the help of the pestle and mortar, then sieved with a $2 \mathrm{~mm}$ sieve net for the physicochemical analysis of the soil. The determination of the soil $\mathrm{pH}$ was done using a $\mathrm{pH}$ meter in 1:2.5 soil: water $(\mathrm{w} / \mathrm{v})$ suspension (Anderson and Ingram 1993). Available phosphorus (Av. P) content in the soil was analyzed following the Bray-1 acid method (Sahrawat et al. 1997) whiles the flame photometer was used to determine the potassium content. The tot. $\mathrm{N}$ was determined by the Kjeldahl method (Sáez-Plaza et al. 2013). Exchangeable bases were extracted with $1.0 \mathrm{M}$ ammonium acetate solution. Sodium and potassium contents in the extract were determined using a flame photometer while calcium and magnesium were determined by Atomic Absorption Spectrophotometer (AAS) (Rhoades et al. 1982). Effective cation exchange capacity (ECEC) was estimated by summation of total exchangeable bases and exchangeable acidity $(\mathrm{Al}+\mathrm{H})$ determined by $1 \mathrm{M} \mathrm{KCl}$ extract and titrated with dilute sodium hydroxide solution (Anderson and Ingram 1993).

\section{Physical characteristics, yield and macro-nutritional composition of collard plant}

Two weeks after transplanting (14 DAT), eight collard plants in each plot were randomly selected and tagged for data collection. Data was collected at 15, 30 and 60

Table 2 Treatment rate of biochar, farmyard manure compost and NPK used in the previous experiment

\begin{tabular}{llll}
\hline Treatment & Biochar (t/ha) & Farmyard manure compost (t/ha) & NPK (kg/ha) \\
\hline Control & 0 & 0 & 0 \\
Compost only (C) & 0 & 10 & 0 \\
NPK & 0 & 0 & 200 \\
Biochar only (B1) & 10 & 0 & 0 \\
Biochar only (B2) & 20 & 0 & 0 \\
Biochar + compost (BC1+CM) & 5 & 5 & 0 \\
Biochar + compost (BC2+CM) & 10 & 5 & 0 \\
Biochar + NPK (BC1+ NPK) & 5 & 0 & 100 \\
Biochar+NPK (BC2+NPK) & 10 & 0 & 100 \\
\hline
\end{tabular}

Table 3 Carbonization characteristics of the ELSA barrel and proximate analysis of the corncob biochar used for the previous experiment

\begin{tabular}{lllllllllll}
\hline Feedstock & $\mathbf{N}$ & Time (Min) & Weight FSt (kg) & Weight BC (kg) & Eff.ww (\%) & Yield (kg/ha) & M (\%) & VM (\%) & ASH (\%) & FC (\%) \\
\hline Corncob & 9 & 49 & 15.5 & 6.75 & 30.67 & 9.13 & 12.40 & 9.24 & 37.96 & 40.41
\end{tabular}

FSt feedstock, $B C$ biochar, Eff efficiency, ww per weight, VM volatile matter, $F C$ fixed carbon, EC electrical conductivity, $M$ moisture content 
DAT on plant height $(\mathrm{cm})$, number of leaves per plant, stem girth $(\mathrm{cm})$, leaf length $(\mathrm{cm})$; plant canopy $(\mathrm{cm})$, total fresh biomass (g) and total dry biomass (g). The stainless steel Vernier caliper was used for the measurement of the stem girth while the tap measure was used to measure the leaf length from the axil to the leaf tip. Collard leaves were harvested and weighed ( $\mathrm{g}$ ) for only one cutting period at 65 days after transplanting (DAT) for the determination of the yield. Collard plant tissue (root, stems and leaves) was immediately weighed to determine the fresh total biomass. For the determination of the nutrient constituents of the collard leaf, freshly harvested collard leaves were weighed separately for each plant per plot for determination of calcium, nitrogen, available phosphorus and potassium compositions of the collard leaf. The harvested leaves were oven-dried for $72 \mathrm{~h}$ and ground into a fine powder using pestle and mortar. A known weight of $0.5 \mathrm{~g}$ of the dried and ground leaves' sample was used for the determination of the N, P, K and Ca. The colorimetric method was used for the determination of phosphorus (Regalado and Cruz 2016). Total potassium and calcium were determined using the flame photometer (Barros et al. 2012) and the nitrogen content was determined by the Kjeldahl method (Sáez-Plaza et al. 2013).

\section{Data analysis}

The data was analyzed using Statistix Edition 8.1 software. One-way ANOVA was used to compare soil physicochemical properties, collard plant biomass and nutritional constituents. Analysis of variance was performed to test the treatment effect for significance and means were separated using Tukey HSD at the 0.05 significance level.

\section{Results}

Residual effects of biochar, farmyard compost and/or NPK applications on soil properties SoilpH

The residual effects of biochar with farmyard compost and NPK applications did not influence the soil $\mathrm{pH}$. The soil $\mathrm{pH}$ varied from 5.35 control to 6.23 at $10 \mathrm{t}$ /ha biochar and $5 \mathrm{t} / \mathrm{ha}$ compost addition plot. The high rate (20 $\mathrm{t} / \mathrm{ha}$ ) of the biochar did not differ in the soil $\mathrm{pH}$ obtained compared to the low rate $(10 \mathrm{t} / \mathrm{ha})$ of the biochar plot. The biochar and compost addition elevated the soil $\mathrm{pH}$ by 0.17 units greater than the solely applied compost. However, the $10 \mathrm{t} /$ ha biochar and $5 \mathrm{t} /$ ha compost addition increased the soil $\mathrm{pH}$ by 0.5 units greater than the $5 \mathrm{t} /$ ha biochar and $5 \mathrm{t} /$ ha compost addition. The biochar (5 t/ha) and NPK (100 kg/ha) addition plot increased the soil $\mathrm{pH}$ by 0.17 units more than the residual plots of the solely applied NPK (Table 4).

\section{Soil available phosphorus}

The soil available phosphorus ranged from $5.48 \mathrm{mg} / \mathrm{kg}$ at control plot to $7.48 \mathrm{mg} / \mathrm{kg}$ at biochar (10 t/ha) and compost $(5 \mathrm{t} / \mathrm{ha})$ addition plot. The high rate of the biochar plot (20 t/ha) elevated the available phosphorus by $2.03 \%$ more than the low rate of the biochar $(10 \mathrm{t} / \mathrm{ha})$. The biochar (10 t/ha) amended soil increased the available phosphorus by $8.98 \%$ greater than the control. The residual effect of biochar and compost addition plot elevated the available phosphorus by $5.32 \%$ greater than the compost plot. The treatment $\mathrm{BC} 1+$ NPK obtained available phosphorus higher than the residual NPK plot by $9.26 \%$. As expected, the $10 \mathrm{t} / \mathrm{ha}$ biochar with NPK and/ compost addition increased the available phosphorus more than the $5 \mathrm{t} / \mathrm{ha}$ biochar with NPK and/ compost addition (Table 4).

\section{Total organic carbon (TOC)}

The total organic carbon varied from $1.36 \%$ at control to $2.78 \%$ at $10 \mathrm{t} /$ ha biochar and $5 \mathrm{t} / \mathrm{ha}$ compost addition. The $10 \mathrm{t} / \mathrm{ha}$ biochar elevated the TOC by $9.04 \%$ more than the control. Biochar improved the TOC with a high rate of biochar application, such that the $10 \mathrm{t} / \mathrm{ha}$ biochar obtained $1.63 \%$ TOC whiles the $20 \mathrm{t} /$ ha biochar plot gained 1. 88\% TOC. The $5 \mathrm{t} / \mathrm{ha}$ biochar and $100 \mathrm{~kg} /$ ha NPK plot showed a higher influence on the TOC than the solely applied NPK, such that the $5 \mathrm{t} /$ ha biochar and $100 \mathrm{~kg} / \mathrm{ha}$ NPK addition plot increased the TOC by $19.3 \%$ greater than the NPK plot. The plot of the combined application of the biochar and farmyard manure compost increased the TOC with an increasing rate of the biochar such that, the $10 \mathrm{t} /$ ha biochar and $5 \mathrm{t} /$ ha farmyard

Table 4 Residual effects of biochar farmyard, compost and/ or NPK applications on the soil pH, total soil organic carbon, nitrogen and available phosphorus

\begin{tabular}{|c|c|c|c|c|}
\hline Treatment & $\mathrm{pH}\left(\mathrm{H}_{2} \mathrm{O}\right)$ & Av.P (mg/kg) & TOC (\%) & N (\%) \\
\hline CTRL & $5.35 b$ & $5.48 f$ & $1.36 \mathrm{e}$ & $0.07 c$ \\
\hline CM & $5.56 a b$ & $6.32 \mathrm{e}$ & 1.60de & $0.10 a b$ \\
\hline NPK & $5.41 \mathrm{~b}$ & $5.54 f$ & $1.40 \mathrm{e}$ & $0.09 \mathrm{bc}$ \\
\hline BC1 & $5.66 a b$ & $6.30 \mathrm{e}$ & 1.63de & $0.11 b c$ \\
\hline $\mathrm{BC} 2$ & $5.74 a b$ & $6.56 \mathrm{~d}$ & $1.88 \mathrm{~cd}$ & $0.12 b c$ \\
\hline $\mathrm{BC} 1+\mathrm{CM}$ & $5.73 a b$ & $7.03 b$ & $2.43 a b$ & $0.13 a b c$ \\
\hline $\mathrm{BC} 2+\mathrm{CM}$ & $6.23 a$ & $7.48 \mathrm{a}$ & $2.78 a$ & $0.18 a$ \\
\hline $\mathrm{BC} 1+\mathrm{NPK}$ & $5.58 \mathrm{ab}$ & $6.68 c$ & $2.07 \mathrm{bc}$ & $0.11 b c$ \\
\hline $\mathrm{BC} 2+\mathrm{NPK}$ & $5.55 a b$ & $7.28 \mathrm{~b}$ & $2.39 b$ & $0.13 a b c$ \\
\hline Significant ${ }^{x}$ & NS & $* * *$ & $* * *$ & $* *$ \\
\hline $\mathrm{SED}^{Y}$ & 0.14 & 0.15 & 0.06 & 0.01 \\
\hline
\end{tabular}

$\mathrm{SED}^{\mathrm{Y}}$ and Significant ${ }^{\mathrm{X}}$ effects were obtained from one-way analysis of variance: $*^{*}{ }^{* *},{ }^{* *}$ Significant at $P<0.05, P<0.01$, and $P<0.001$, respectively. See Table 2 for a description of the treatments; Means followed by the same letter in each column are not significantly different at $p \leq 0.05$ using Tukey HSD 
compost addition plot obtained a higher TOC of $2.78 \%$ compared with a TOC of $2.43 \%$ recorded by the $5 \mathrm{t} / \mathrm{ha}$ biochar and $5 \mathrm{t} /$ ha farmyard compost plot (Table 4 ).

\section{Total nitrogen ( $N$ )}

There was a significant $(\mathrm{p}<0.05)$ increased in soil total nitrogen among the treatments. The nitrogen ranged from 0.08 at control to $0.18 \%$ at $10 \mathrm{t} / \mathrm{ha}$ biochar and 5 $\mathrm{t} / \mathrm{ha}$ compost addition plot. The $10 \mathrm{t} / \mathrm{ha}$ biochar plot increased the nitrogen by $15.78 \%$ more than the control. The combined biochar ( $5 \mathrm{t} / \mathrm{ha}$ ) and compost $(5 \mathrm{t} /$ ha) addition plot increased the nitrogen by $13.04 \%$ more than the solely applied compost plot. However, the $5 \mathrm{t} / \mathrm{ha}$ biochar and the NPK addition plot did not significantly influence the nitrogen obtained compared to the solely applied NPK plot (Table 4).

\section{Exchangeable bases $\left(\mathrm{K}^{+}, \mathrm{Mg}^{2+} \mathrm{Ca}^{2+} \mathrm{Na}^{+}\right)$}

Statistically, the differences among means were significant in the potassium, calcium, sodium and magnesium content as the result of the residual effect of the biochar, farmyard compost and NPK applications. The potassium content varied from $0.16 \mathrm{cmol} / \mathrm{kg}$ at control to $0.46 \mathrm{cmol} /$ $\mathrm{kg}$ at biochar and NPK addition plot. The co-applied biochar with NPK and/ compost obtained a higher potassium content more than the solely applied compost and the NPK. The calcium content varied from $1.57 \mathrm{cmol} /$ $\mathrm{kg}$ to $3.38 \mathrm{cmol} / \mathrm{kg}$ with the highest obtained by the 10 $\mathrm{t} / \mathrm{ha}$ biochar and $5 \mathrm{t} / \mathrm{ha}$ compost addition. There was no significant difference between the solely applied $10 \mathrm{t} / \mathrm{ha}$ biochar and the $20 \mathrm{t} / \mathrm{h}$ a biochar. However, the $5 \mathrm{t} / \mathrm{ha}$ biochar and $5 \mathrm{t} /$ ha compost increased the calcium content by $10.76 \%$ more than the solely applied compost. Similarly, the combined $5 \mathrm{t} / \mathrm{ha}$ biochar and $100 \mathrm{~kg} / \mathrm{ha}$ NPK increased the calcium content by $15.44 \%$ greater than the solely applied NPK. The combined application of biochar and farmyard manure compost increased the calcium content with an increasing rate of the biochar such that, the $10 \mathrm{t} / \mathrm{ha}$ biochar and $5 \mathrm{t} / \mathrm{ha}$ farmyard compost addition plot obtained higher calcium content of $3.38 \mathrm{cmol} /$ $\mathrm{kg}$ compared with the calcium content of $2.47 \mathrm{cmol} / \mathrm{kg}$ recorded by the $5 \mathrm{t} /$ ha biochar and $5 \mathrm{t} / \mathrm{ha}$ farmyard compost plot. Varying sodium content was observed, ranging from $0.16 \mathrm{cmol} / \mathrm{kg}$ at $20 \mathrm{t} / \mathrm{ha}$ biochar to $0.38 \mathrm{cmol} / \mathrm{kg}$ at $10 \mathrm{t} / \mathrm{ha}$ biochar and $100 \mathrm{~kg} / \mathrm{ha}$ NPK plots. The sodium content decreased as biochar increased such that, $20 \mathrm{t} /$ ha biochar obtained a sodium content of $0.16 \mathrm{cmol} / \mathrm{kg}$ compared to $0.21 \mathrm{cmol} / \mathrm{kg}$ obtained by $10 \mathrm{t} / \mathrm{ha}$ biochar plot. As usual, the combined biochar with NPK and/ compost increased the sodium content greater than the solely applied NPK and compost. The magnesium content differ from $0.45 \mathrm{cmol} / \mathrm{kg}$ at control to $0.74 \mathrm{cmol} / \mathrm{kg}$ at $10 \mathrm{t} / \mathrm{ha}$ biochar and $5 \mathrm{t} / \mathrm{ha}$ compost addition plot. The sole application of the $10 \mathrm{t} /$ ha biochar increased the magnesium content by $13.46 \%$ more than the control. The combined $5 \mathrm{t} / \mathrm{ha}$ biochar and $5 \mathrm{t} / \mathrm{ha}$ compost increased the magnesium content by $7.44 \%$ more than the solely applied compost. Also, the combined application of biochar and NPK increased the magnesium content with an increasing rate of the biochar such that, the $10 \mathrm{t} / \mathrm{ha}$ biochar and $100 \mathrm{~kg} / \mathrm{ha}$ addition plots obtained a higher magnesium content of $0.65 \mathrm{cmol} / \mathrm{kg}$ compared with the magnesium content of $0.55 \mathrm{cmol} / \mathrm{kg}$ being recorded by the $5 \mathrm{t} / \mathrm{ha}$ biochar and $100 \mathrm{~kg} / \mathrm{ha}$ plot (Table 5).

\section{Effective cation exchange capacity (ECEC)}

The residual effect of biochar, farmyard manure compost and/NPK applications significantly $(\mathrm{p}<0.05)$ increased the effective cation exchange capacity (ECEC). The ECEC ranged from $2.37 \mathrm{cmol} / \mathrm{kg}$ at control to $4.75 \mathrm{cmol} /$ $\mathrm{kg}$ at $10 \mathrm{t} / \mathrm{ha}$ biochar and $5 \mathrm{t} / \mathrm{ha}$ compost addition. The biochar and compost addition increased the ECEC by $10.36 \%$ more than the solely applied compost while the combined $5 \mathrm{t} / \mathrm{ha}$ biochar and $100 \mathrm{~kg} / \mathrm{ha}$ NPK addition elevated the ECEC by $10.32 \%$ more than the NPK plot. Doubling the biochar rate elevated the ECEC by $21.92 \%$ more than the control (Fig. 1).

\section{Residual effects of biochar, farmyard compost and/NPK applications on collard growth development and yield Collard plant canopy, plant height, plant stem and number of leaves at 15 DAT}

The residual effects of co-applied Biochar with Farmyard compost and NPK applications significantly $(\mathrm{p}<0.05)$ increased plant canopy and plant height at 15 DAT. The plant canopy ranged from $34.10 \mathrm{~cm}$ at control to $42.10 \mathrm{~cm}$ at $10 \mathrm{t} / \mathrm{ha}$ biochar and $100 \mathrm{~kg} / \mathrm{ha}$ NPK addition plot. The $10 \mathrm{t} / \mathrm{ha}$ biochar and $5 \mathrm{t} / \mathrm{ha}$ compost addition increased the plant canopy by $3.14 \%$ more than the $5 \mathrm{t} /$ ha biochar and $5 \mathrm{t} / \mathrm{ha}$ compost addition plot. The plant height varied from $23.58 \mathrm{~cm}$ at control to $32.88 \mathrm{~cm}$ at $10 \mathrm{t} / \mathrm{ha}$ biochar and $100 \mathrm{~kg} / \mathrm{ha}$ NPK addition. The $10 \mathrm{t} /$ ha biochar plot increased the plant height by $6.1 \%$ more than the control. The $20 \mathrm{t} / \mathrm{ha}$ of the biochar addition plot increased the plant height by $6.98 \%$ more than the sole application of the $10 \mathrm{t} /$ ha biochar. The $5 \mathrm{t} / \mathrm{ha}$ biochar and $5 \mathrm{t} /$ ha compost addition plot increased the plant height by $0.64 \%$ compared to the sole application of the $10 \mathrm{t} / \mathrm{ha}$ compost plot while $5 \mathrm{t} / \mathrm{ha}$ biochar and $100 \mathrm{~kg} / \mathrm{ha} \mathrm{NPK}$ addition plot increased the plant height by $10.58 \%$ more than the sole application of the NPK. The collard plant stem and the number of leaves were not significantly influenced by the residual effects of co-applied biochar with farmyard compost and NPK. The plant stem varied from $0.38 \mathrm{~cm}$ at control to $0.70 \mathrm{~cm}$ at $10 \mathrm{t} /$ ha biochar and $100 \mathrm{~kg} / \mathrm{ha}$ NPK addition plot while the number of collard 
Table 5 Residual effects of biochar farmyard, compost and/or NPK applications on the exchangeable bases $\left(\mathrm{K}^{+}, \mathrm{Mg}^{2+} \mathrm{Ca}^{2+} \mathrm{Na}^{+}\right)$

\begin{tabular}{|c|c|c|c|c|}
\hline Treatment & Potassium $(\mathrm{cmol} / \mathrm{kg})$ & Calcium (cmol/kg) & Sodium (cmol/kg) & $\begin{array}{l}\text { Magnesium } \\
(\mathrm{cmol} / \mathrm{kg})\end{array}$ \\
\hline CTRL & $0.16 c$ & $1.57 \mathrm{e}$ & $0.20 \mathrm{~cd}$ & $0.45 e$ \\
\hline CM & $0.28 b c$ & $1.99 \mathrm{~cd}$ & $0.24 c$ & $0.56 \mathrm{~cd}$ \\
\hline NPK & $0.36 a b$ & $1.67 \mathrm{de}$ & $0.36 a$ & $0.51 \mathrm{de}$ \\
\hline $\mathrm{BC} 1$ & $0.34 a b$ & 1.80de & $0.21 \mathrm{~cd}$ & $0.59 b c$ \\
\hline $\mathrm{BC2}$ & $0.39 \mathrm{ab}$ & $2.51 \mathrm{~b}$ & $0.16 d$ & $0.65 b$ \\
\hline $\mathrm{BC} 1+\mathrm{CM}$ & $0.38 \mathrm{ab}$ & $2.47 b$ & $0.20 \mathrm{bc}$ & $0.67 a b$ \\
\hline $\mathrm{BC} 2+\mathrm{CM}$ & $0.43 a$ & $3.38 \mathrm{a}$ & $0.26 \mathrm{~cd}$ & $0.74 a$ \\
\hline$B C 1+N P K$ & $0.44 a$ & $2.28 \mathrm{bc}$ & $0.32 \mathrm{ab}$ & $0.55 \mathrm{~cd}$ \\
\hline $\mathrm{BC} 2+\mathrm{NPK}$ & $0.46 a$ & $2.48 b$ & $0.38 a$ & $0.65 b$ \\
\hline Significant ${ }^{\mathrm{x}}$ & $* * *$ & $* * *$ & $* * *$ & $* * *$ \\
\hline $\mathrm{SED}^{Y}$ & 0.03 & 0.06 & 0.01 & 0.01 \\
\hline
\end{tabular}

Significant ${ }^{x}$ effects were obtained from one-way analysis of variance: ${ }^{*},{ }^{* *}$, ***Significant at $P<0.05, P<0.01$, and $P<0.001$, respectively. See Table 2 for a description of the treatments; Means followed by the same letter in each column are not significantly different at $p \leq 0.05$ using Tukey HSD
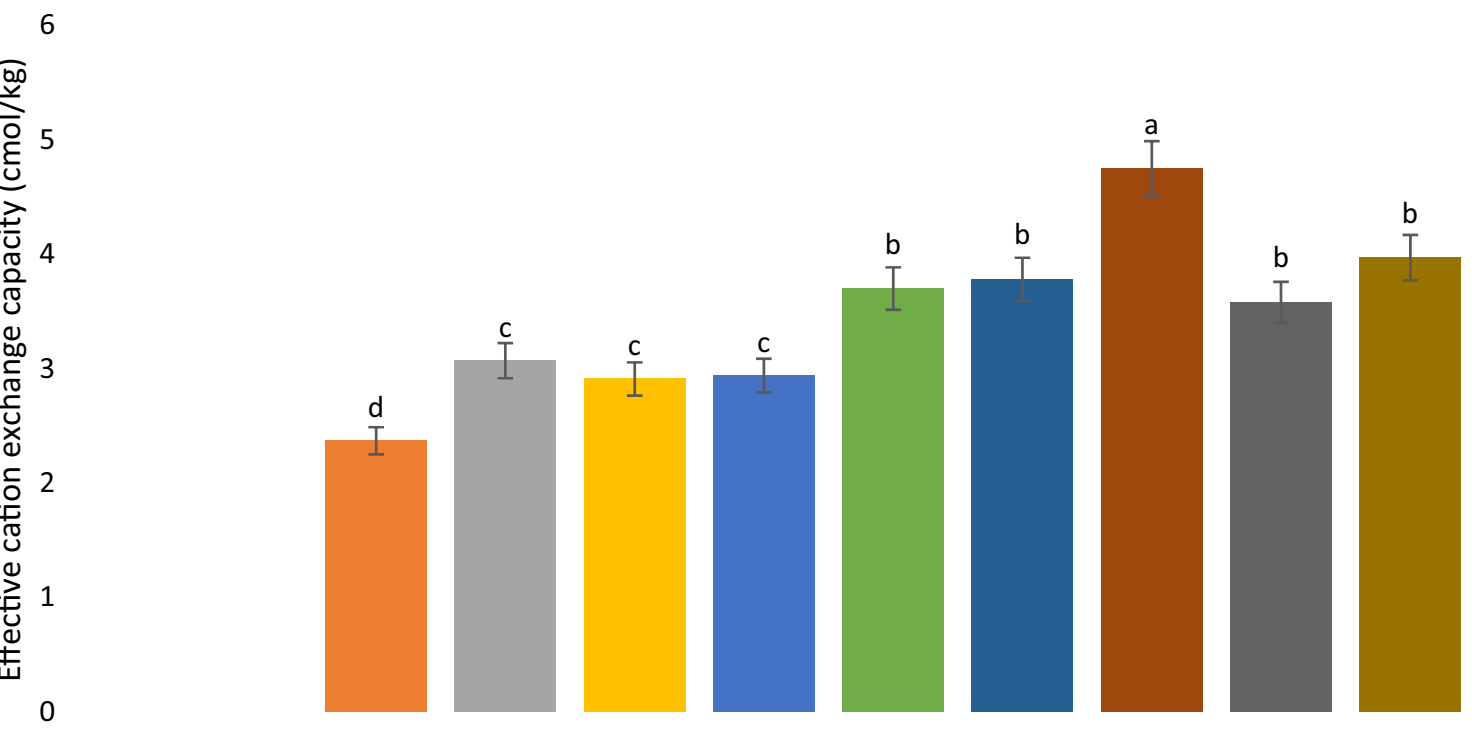

$\square \mathrm{CTRL} \square \mathrm{CM} \square \mathrm{NPK} \square \mathrm{BC} 1 \quad \mathrm{BC2} \square \mathrm{BC} 1+\mathrm{CM} \square \mathrm{BC} 2+\mathrm{CM} \square \mathrm{BC} 1+\mathrm{NPK} \square \mathrm{BC} 2+\mathrm{NPK}$

Fig. 1 Residual effect of biochar, farmyard manure compost and/NPK on the on the effective cation exchange capacity. The same letter on the bars are not significantly different at $p \leq 0.05$ using Tukey HSD. Error bars represent standard deviation of the means

leaves ranged from 7.6 at control plot to 9.66 at $10 \mathrm{t} / \mathrm{ha}$ biochar and $100 \mathrm{~kg} / \mathrm{ha}$ NPK addition plot (Table 6).

\section{Plant canopy, plant height, plant stem and number of leaves at 30 DAT}

The residual effect of biochar with farmyard manure compost and/or NPK showed a significantly $(\mathrm{p}<0.05)$ increased plant canopy, plant height and plant stem at 30 DAT. The plant height ranged from $44.73 \mathrm{~cm}$ at control to $63.25 \mathrm{~cm}$ at $10 \mathrm{t} / \mathrm{ha}$ biochar and $100 \mathrm{~kg} / \mathrm{ha}$ NPK addition plot. The $5 \mathrm{t} /$ ha biochar and $5 \mathrm{t} / \mathrm{ha}$ compost addition plot increased the plant canopy by $3.58 \%$ compared to the sole application of the $10 \mathrm{t} / \mathrm{ha}$ compost plot while 5 $\mathrm{t} / \mathrm{ha}$ biochar and $100 \mathrm{~kg} / \mathrm{ha}$ NPK addition plot increased the plant height by $6.96 \%$ more than the NPK plot. The $10 \mathrm{t} / \mathrm{ha}$ biochar plot increased the collard plant canopy by $8.04 \%$ more than the control. The high rate $(20 \mathrm{t} / \mathrm{ha})$ of the biochar plot did not differ from the low rate $(10 \mathrm{t} /$ 
ha) biochar plot of the plant canopy obtained. The plant height varied from $33.85 \mathrm{~cm}$ at control to 46.19 at $10 \mathrm{t} /$ ha biochar and $100 \mathrm{~kg} / \mathrm{ha}$ NPK addition plot. The biochar and compost addition plot showed higher plant height than the sole compost plot. The $15 \mathrm{t} / \mathrm{ha}$ compost and $100 \mathrm{~kg} / \mathrm{ha}$ NPK addition plot increased plant height by $10.64 \%$ more than the solely applied NPK. The collard plant stem girth varied from $0.63 \mathrm{~cm}$ at control to $0.94 \mathrm{~cm}$ at $10 \mathrm{t} / \mathrm{ha}$ biochar and $100 \mathrm{~kg} / \mathrm{ha}$ NPK plot. The biochar and compost addition plot obtained a higher stem girth more than the sole application of the compost. The collard plant number of leaves was not significantly influenced by the residual effects of co-applied Biochar with Farmyard compost and/or NPK. The number of leaves varied from 10.28 at $5 \mathrm{t} / \mathrm{ha}$ biochar and $5 \mathrm{t} / \mathrm{ha}$ compost addition plot to 11.28 at solely $10 \mathrm{t} / \mathrm{ha}$ biochar plot (Table 7).

\section{Plant canopy, plant height, plant stem and number of leaves at 60 DAT}

Varying plant canopy, plant height and stem girth were observed as a result of the biochar with farmyard manure compost and NPK at 60 DAT. The plant canopy varied from $69.93 \mathrm{~cm}$ at the control plot to $90.14 \mathrm{~cm}$ at 10 $\mathrm{t} / \mathrm{ha}$ biochar and $100 \mathrm{~kg} / \mathrm{ha}$ plot. The biochar and compost addition plot obtained a higher plant canopy than the sole application of the compost. As expected, the 15 $\mathrm{t} / \mathrm{ha}$ biochar and $100 \mathrm{~kg} / \mathrm{ha}$ addition plot increased the plant canopy by $6.68 \%$ more than the NPK plot. The plant height ranged from $61.40 \mathrm{~cm}$ at control to $77.22 \mathrm{~cm}$ at 10 $\mathrm{t} / \mathrm{ha}$ biochar and $100 \mathrm{~kg} / \mathrm{ha}$ NPK addition. The plot of the low rate (10 t/ha) and high rate biochar (20 t/ha) did not differ regarding the plant height observed. However, the plot of the biochar and compost addition obtained higher plant height more than the sole application of the compost. The stem girth ranged from $1.92 \mathrm{~cm}$ at control to $3.62 \mathrm{~cm}$ at $10 \mathrm{t} / \mathrm{ha}$ biochar and $100 \mathrm{~kg} / \mathrm{ha}$ NPK addition plot. The collard plant number of leaves was not significantly influenced by the residual effects of the co-applied biochar with farmyard compost and NPK (Table 8).

\section{Collard plant leaf length}

The leaf length did not differ significantly $(P>0.05)$ among the treatments in the 15 and 30 DAT but differ significantly $(\mathrm{P}<0.05)$ at 45 and 60 DAT. During the 45 DAT, the $20 \mathrm{t} /$ ha biochar plot obtained the higher leaf length but was not significant $(\mathrm{P}>0.05)$ compared to the co-applied biochar with compost and/NPK application plot, however, $10 \mathrm{t} / \mathrm{ha}$ biochar and $100 \mathrm{~kg} / \mathrm{ha}$ NPK obtained the higher leaf length at 45 DAT (Fig. 2).

\section{Residual effects of biochar farmyard compost and/or NPK applications on collard plant yield and fresh total plant biomass at 60 DAT}

Collard plant yield The yield differs significantly $(\mathrm{P}>0.05)$ among the treatments. The yield ranged from $458.19 \mathrm{~g} /$ plant at control to $588.79 \mathrm{~g} /$ plant at treatment $\mathrm{BC} 2+\mathrm{CM}$. The combined $5 \mathrm{t} / \mathrm{ha}$ biochar and $5 \mathrm{t} / \mathrm{ha}$ compost increased the yield by $5.08 \%$ more than the solely applied compost. However, it did not differ as compared to the $10 \mathrm{t} / \mathrm{ha}$ biochar and $5 \mathrm{t} / \mathrm{ha}$ compost. The $5 \mathrm{t} / \mathrm{ha}$ biochar and $100 \mathrm{~kg} / \mathrm{ha}$ NPK increased the yield by $4.16 \%$ more than the solely applied NPK (Fig. 3).

Table 6 Residual effects of co-applied biochar with compost and/or NPK collard plant canopy, plant height, plant stem and the number of leaves at 15 DAT

\begin{tabular}{|c|c|c|c|c|}
\hline Treatment & Plant canopy $(\mathrm{cm})$ & Plant height (cm) & Plant stem (cm) & $\begin{array}{l}\text { Number } \\
\text { of leaves }\end{array}$ \\
\hline CTRL & $34.10 a$ & $23.58 c$ & $0.38 a$ & $7.28 \mathrm{a}$ \\
\hline CM & $34.20 a$ & $30.62 a$ & $0.44 a$ & $7.86 a$ \\
\hline NPK & $35.73 a$ & $24.64 b c$ & $0.40 a$ & $7.60 \mathrm{a}$ \\
\hline $\mathrm{BC} 1$ & $38.65 a$ & $26.64 a$ & $0.45 a$ & $7.69 a$ \\
\hline $\mathrm{BC} 2$ & $33.36 a$ & $30.64 a b$ & $0.42 \mathrm{a}$ & $7.84 a$ \\
\hline $\mathrm{BC} 1+\mathrm{CM}$ & $38.75 a$ & $31.01 a$ & $0.45 a$ & $8.38 a$ \\
\hline $\mathrm{BC} 2+\mathrm{CM}$ & $39.84 a$ & $32.42 a$ & $0.48 a$ & $7.68 \mathrm{a}$ \\
\hline $\mathrm{BC} 1+\mathrm{NPK}$ & $39.53 a$ & $30.47 a$ & $0.47 a$ & $7.81 \mathrm{a}$ \\
\hline $\mathrm{BC} 2+\mathrm{NPK}$ & $42.10 \mathrm{~b}$ & $32.88 a$ & $0.70 a$ & $9.66 a$ \\
\hline Significant ${ }^{x}$ & * & $* * *$ & NS & NS \\
\hline $\mathrm{SED}^{Y}$ & 2.66 & 2.01 & 0.13 & 1.32 \\
\hline
\end{tabular}

Significant ${ }^{X}$ and SED ${ }^{Y}$ effects were obtained from one-way analysis of variance: ${ }^{*},{ }^{* *},{ }^{* * *}$ significant at $P<0.05, P<0.01$, and $P<0.001$, respectively. See Table 2 for a description of the treatments; Means followed by the same letter in each column are not significantly different at $p \leq 0.05$ using Tukey HSD 
Table 7 Residual effects of co-applied biochar with compost and/or NPK collard plant canopy, plant height, plant stem and number of leaves at 30 DAT

\begin{tabular}{|c|c|c|c|c|}
\hline Treatment & Plant canopy $(\mathrm{cm})$ & Plant height $(\mathrm{cm})$ & Plant stem $(\mathrm{cm})$ & Number of leaves \\
\hline CTRL & $44.73 b$ & $33.85 \mathrm{a}$ & $0.63 b$ & $10.69 a$ \\
\hline CM & 53.53ab & $41.08 \mathrm{a}$ & $0.79 a b$ & $10.78 a$ \\
\hline NPK & $51.98 a b$ & $36.34 a$ & $0.70 a b$ & $10.56 a$ \\
\hline $\mathrm{BC} 1$ & 55.19ab & $42.43 a b$ & $0.77 a b$ & $11.28 \mathrm{a}$ \\
\hline $\mathrm{BC} 2$ & 56.19ab & $43.581 \mathrm{ab}$ & $0.81 a b$ & $10.75 a$ \\
\hline $\mathrm{BC} 1+\mathrm{CM}$ & $57.50 \mathrm{ab}$ & $44.58 a b$ & $0.79 a b$ & $10.28 \mathrm{a}$ \\
\hline $\mathrm{BC} 2+\mathrm{CM}$ & $59.05 a$ & $45.98 b$ & $0.82 a b$ & $10.56 a$ \\
\hline $\mathrm{BC} 1+\mathrm{NPK}$ & $59.75 a$ & 44.99ab & $0.84 a b$ & $10.88 a$ \\
\hline $\mathrm{BC} 2+\mathrm{NPK}$ & $63.25 a$ & $46.19 b$ & $0.94 a$ & $10.63 a$ \\
\hline Significant ${ }^{x}$ & $* *$ & $* * *$ & * & NS \\
\hline $\mathrm{SED}^{Y}$ & 3.83 & 2.17 & 0.08 & 0.47 \\
\hline
\end{tabular}

Significant ${ }^{X}$ and SED ${ }^{Y}$ effects were obtained from one-way analysis of variance: ${ }^{*},{ }^{* *},{ }^{* * *}$ significant at $P<0.05, P<0.01$, and $P<0.001$, respectively. See Table 2 for a description of the treatments; Means followed by the same letter in each column are not significantly different at $p \leq 0.05$ using Tukey HSD

Table 8 Residual effects of co-applied biochar with compost and/or NPK collard plant canopy, plant height, plant stem and the number of leaves at 60 DAT

\begin{tabular}{|c|c|c|c|c|}
\hline Treatment & Plant canopy $(\mathrm{cm})$ & Plant height $(\mathrm{cm})$ & Plant stem girth $(\mathrm{cm})$ & Number of leaves \\
\hline CTRL & $69.93 b$ & $61.40 \mathrm{e}$ & $1.92 b$ & $12.88 \mathrm{a}$ \\
\hline CM & $72.09 b$ & 65.04cde & $2.08 b$ & $13.00 \mathrm{a}$ \\
\hline NPK & $70.84 b$ & $63.10 \mathrm{de}$ & $1.97 \mathrm{~b}$ & $13.59 a$ \\
\hline$B C 1$ & $78.25 \mathrm{ab}$ & $67.52 \mathrm{bcde}$ & $2.08 b$ & $13.13 a$ \\
\hline $\mathrm{BC} 2$ & $76.68 b$ & $67.82 \mathrm{bcde}$ & $2.12 b$ & $13.06 a$ \\
\hline $\mathrm{BC} 1+\mathrm{CM}$ & $78.85 a b$ & $69.11 \mathrm{bcd}$ & $2.08 b$ & $13.31 a$ \\
\hline $\mathrm{BC} 2+\mathrm{CM}$ & $82.10 \mathrm{ab}$ & $70.73 a b c$ & $2.39 b$ & $13.43 a$ \\
\hline $\mathrm{BC} 1+\mathrm{NPK}$ & 81.19ab & 73.48ab & $2.43 b$ & $13.13 a$ \\
\hline $\mathrm{BC} 2+\mathrm{NPK}$ & $90.14 a$ & $77.22 \mathrm{a}$ & $3.62 \mathrm{a}$ & $14.03 a$ \\
\hline Significant $^{x}$ & $* * *$ & $* * *$ & $* *$ & NS \\
\hline $\mathrm{SED}^{Y}$ & 3.90 & 2.23 & 0.29 & 0.72 \\
\hline
\end{tabular}

Significant ${ }^{X}$ and SED ${ }^{Y}$ effects were obtained from one-way analysis of variance: ${ }^{*}{ }^{* *}{ }^{*}{ }^{* *}$ Significant at $P<0.05, P<0.01$, and $P<0.001$, respectively. See Table 2 for a description of the treatments; Means followed by the same letter in each column are not significantly different at $p \leq 0.05$ using Tukey HSD

Fresh total plant biomass The residual effect of the coapplied biochar with farmyard manure compost and/or NPK observed a significant $(\mathrm{p}<0.05)$ increased in available phosphorus The fresh total plant biomass varied from $649.03 \mathrm{~g}$ at control to $925.27 \mathrm{~g}$ at $10 \mathrm{t} / \mathrm{ha}$ biochar and $5 \mathrm{t} /$ ha compost addition plot. The $5 \mathrm{t} / \mathrm{ha}$ biochar and $5 \mathrm{t} / \mathrm{ha}$ compost addition plot increased the fresh total biomass by $7.44 \%$ more than the solely applied compost plot. As expected, the $5 \mathrm{t} / \mathrm{ha}$ biochar and $100 \mathrm{~kg} / \mathrm{ha}$ NPK elevated the fresh total biomass by $0.46 \%$ more than the solely applied NPK (Fig. 4).

\section{Residual effects of biochar, farmyard compost and NPK applications on nutrient constituents of collard leaf at 60 DAT \\ Macronutrient composition ( $N, P, K, C a)$ of collard leaf}

The residual effects of biochar with farmyard compost and/NPK applications significantly $(\mathrm{P}<0.05)$ increased the nitrogen, potassium, calcium and available phosphorus content of the dry matter biomass of the collard leaf. The nitrogen of the dry collard leaf ranged from $0.66 \%$ at control to $2.01 \%$ at $10 \mathrm{t} /$ ha biochar and $5 \mathrm{t} / \mathrm{ha}$ compost addition plot. The combined application of the biochar and the compost and/NPK addition plot elevated the N content in the collard leaf more than the the sole application of the compost and the NPK. The potassium content of the collard leaf varied from $0.94 \%$ at control to $3.51 \%$ 
60

\section{0}

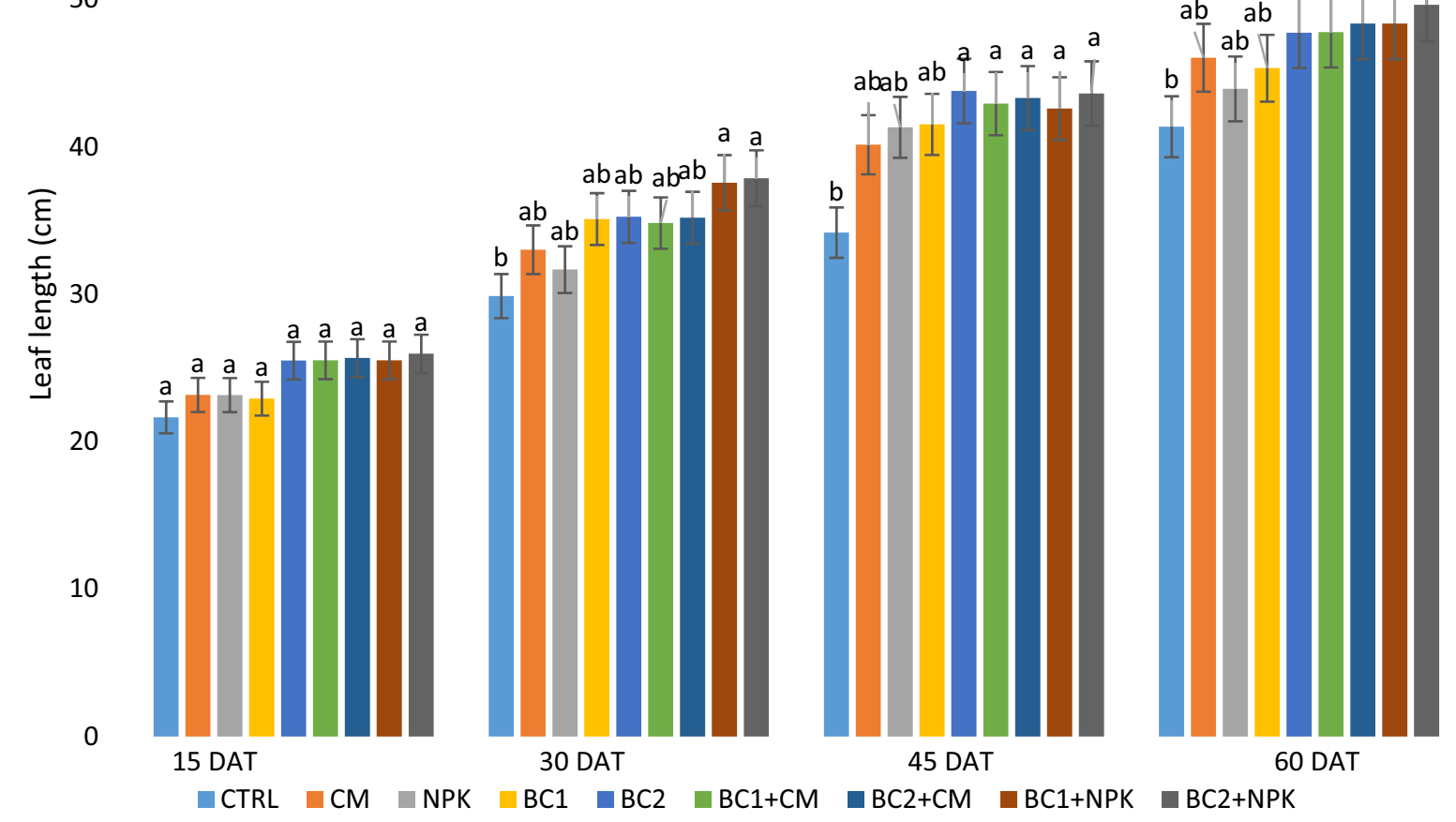

Fig. 2 Residual Effect of biochar, farmyard manure compost and/or NPK on the collard plant leaf length. The same letter on the bars are not significantly different at $\mathrm{p} \leq 0.05$ using Tukey HSD; Control (CTRL), 10 t/ha compost only (CM), $200 \mathrm{~kg} \mathrm{NPK}$ (NPK), 10t/ha Biochar only (BC1), $20 \mathrm{t} /$ ha Biochar only (BC2), $5 \mathrm{t} / \mathrm{ha}$ Biochar $+5 \mathrm{t} / \mathrm{ha}$ compost $(\mathrm{BC} 1+\mathrm{CM}), 10 \mathrm{t} / \mathrm{ha}$ Biochar $+5 \mathrm{t} / \mathrm{ha}$ compost $(\mathrm{BC} 2+\mathrm{CM}), 5 \mathrm{t} / \mathrm{ha} \mathrm{Biochar}+100 \mathrm{~kg} / \mathrm{ha} \mathrm{NPK}$ $(\mathrm{BC} 1+\mathrm{NPK}), 10 \mathrm{t} / \mathrm{ha}$ Biochar $+100 \mathrm{~kg} / \mathrm{ha}$ NPK (BC2+NPK); Error bars represent standard deviation of the means

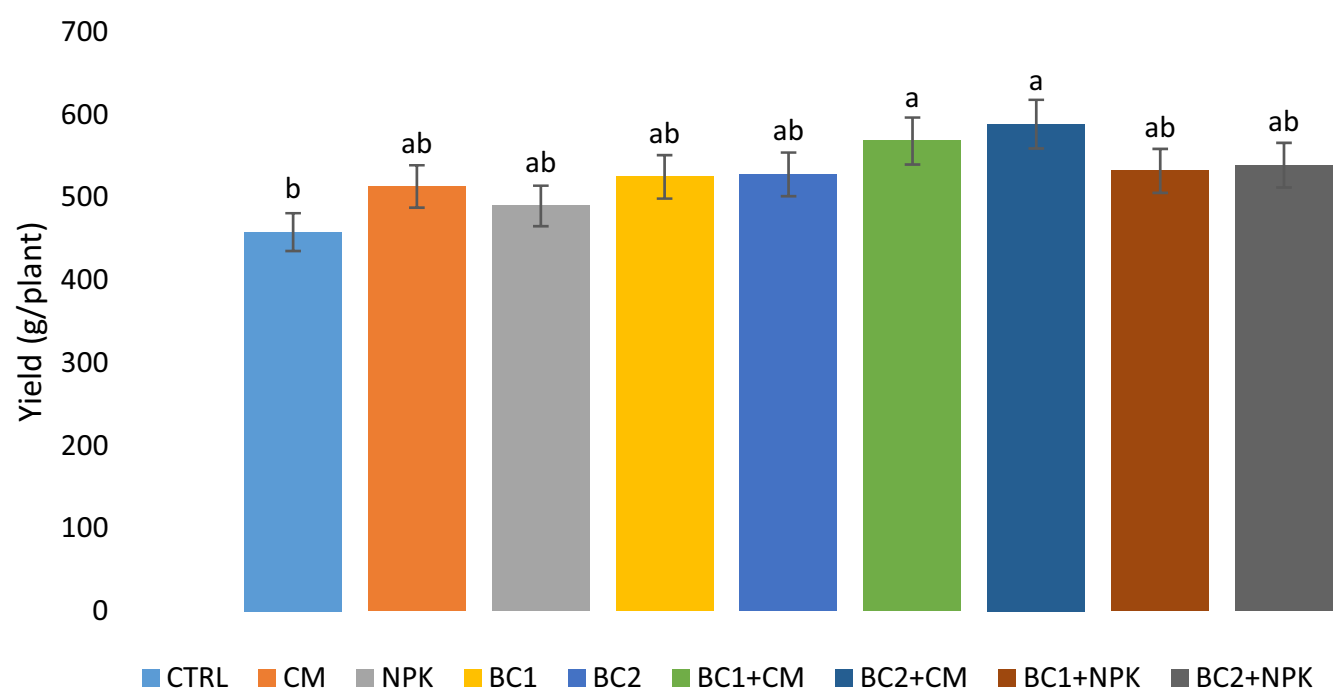

Fig. 3 Residual Effect of biochar, farmyard manure compost and/NPK on the collard plant yield. The same letter on the bars are not significantly different at $p \leq 0.05$ using Tukey HSD; Control(CTRL), 10 t/ha compost only (CM), $200 \mathrm{~kg} \mathrm{NPK,} \mathrm{10t/ha} \mathrm{Biochar} \mathrm{only} \mathrm{(BC1),} 20$ t/ha Biochar only (BC2), $5 \mathrm{t} / \mathrm{ha}$ Biochar $+5 \mathrm{t} / \mathrm{ha}$ compost $(\mathrm{BC} 1+\mathrm{CM}), 10 \mathrm{t} / \mathrm{ha}$ Biochar $+5 \mathrm{t} / \mathrm{ha}$ compost $(\mathrm{BC} 2+\mathrm{CM}), 5 \mathrm{t} / \mathrm{ha}$ Biochar $+100 \mathrm{~kg} / \mathrm{ha} \mathrm{NPK}(\mathrm{BC} 1+\mathrm{NPK}), 10 \mathrm{t} / \mathrm{ha}$ Biochar $+100 \mathrm{~kg} / \mathrm{ha}$ NPK (BC2+NPK); Error bars represent standard deviation of the means 
at $10 \mathrm{t} / \mathrm{ha}$ biochar and $5 \mathrm{t} / \mathrm{ha}$ compost addition plot. Treatment $\mathrm{BC} 1+\mathrm{CM}$ increased the potassium content of the collard leaf by $10.55 \%$ more than the solely applied compost. The combined application of NPK and the biochar also increased the potassium content more than the solely applied NPK. The calcium content varied from 1.32 at control to 4.99 at $10 \mathrm{t} / \mathrm{ha}$ biochar and $5 \mathrm{t} / \mathrm{ha}$ compost addition plot. The co-applied biochar with the compost and/NPK increased the calcium content more than the solely applied compost and/NPK. The available phosphorus content varied from $0.38 \%$ at control to $1.41 \%$ at $10 \mathrm{t} /$ ha biochar and $5 \mathrm{t} /$ ha compost addition plot increasing the biochar content increased the phosphorus content, such that the $10 \mathrm{t} /$ ha biochar obtained $0.74 \%$ of the phosphorus in the collard leaf while $1.17 \%$ was observed by the $20 \mathrm{t} / \mathrm{ha}$ biochar. Also, the combined application of the biochar with compost and/NPK showed a higher phosphorus content than the solely applied compost and the NPK (Table 9).

\section{Discussion}

In the present study, the residual effects of co-applied biochar with compost and NPK showed a positive impact on the reclamation of highly degraded soil. The increase in the soil $\mathrm{pH}$ in the residual biochar plots resulted from the functions of the biochar to released cation oxides for the replacement of the hydrogen and aluminum iron on the colloidal soil surface, resulting in the decrease of the exchangeable acidity as reported by Jien and
Wang (2013). A similar result observation was made by Yuan et al. 2011, in which they concluded that biochar increased soil $\mathrm{pH}$ on a long-term basis. The results are in accordance with Frimpong et al. (2020) who reported a $\mathrm{pH}$ increased in a one-time application of biochar across three cropping cycles on highly weathered tropical soil. The higher soil $\mathrm{pH}$ in the residual biochar and compost addition plot than the residual biochar and NPK addition plot could be probably due to the greater liming potential of the biochar and compost in the long term than the biochar and NPK addition.

Increased CEC in the residual biochar and the compost addition plot could probably assign to the larger specific areas of the residual biochar particles in the soil environment which continue to increase the sorption capacity and base saturation of the soil environment (Chen et al. 2011). According to Lehmann Joseph (2015), biochar residues in the soil can have larger negative charges on their surface, which is attributed to the formation of the phenolic group by abiotic oxidation, hence contributing to the increase of the CEC in the soil environment. Also, as a result of the high surface area of the biochar, it adsorbed the organic matter derived from the compost and the soil environment on its surface, causing the slow release of carboxylic and phenolic acid groups into the soil environment (Novak et al. 2009). The carbon provided by the biochar in the previous amendment contributed to the TOC because $\mathrm{C}$ added from biochar is resistant to microbial attack or degradation and $\mathrm{C}$ added from biochar into the soil can be eliminated from the soil

1200

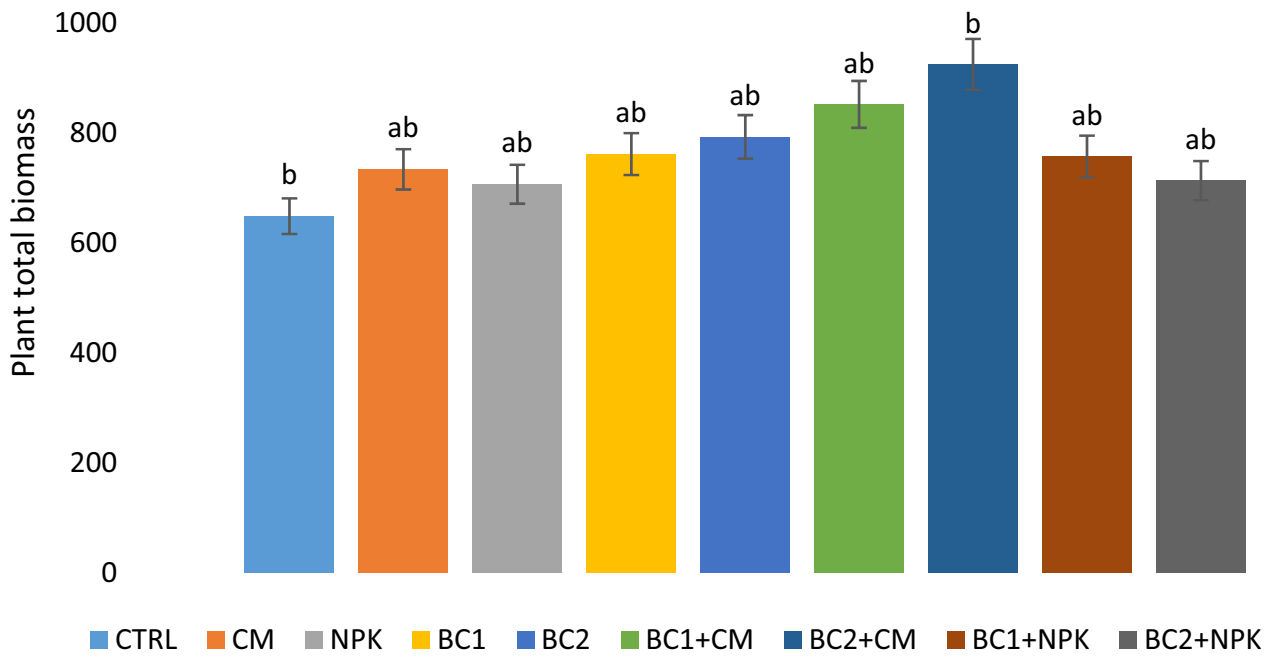

Fig. 4 Residual Effect of biochar, farmyard manure compost and/or NPK on the fresh total collard plant biomass. The same letter on the bars are not significantly different at $p \leq 0.05$ using Tukey HSD; Control(CTRL), 10 t/ha compost only (CM), $200 \mathrm{~kg} \mathrm{NPK} \mathrm{(NPK),} \mathrm{10t/ha} \mathrm{Biochar} \mathrm{only} \mathrm{(BC1),} 20$ $\mathrm{t} /$ ha Biochar only (BC2), $5 \mathrm{t} / \mathrm{ha}$ Biochar $+5 \mathrm{t} / \mathrm{ha}$ compost $(\mathrm{BC} 1+\mathrm{CM}), 10 \mathrm{t} / \mathrm{ha} \mathrm{Biochar}+5 \mathrm{t} / \mathrm{ha}$ compost $(\mathrm{BC} 2+\mathrm{CM}), 5 \mathrm{t} / \mathrm{ha} \mathrm{Biochar}+100 \mathrm{~kg} / \mathrm{ha} \mathrm{NPK}$ $(\mathrm{BC} 1+\mathrm{NPK}), 10 \mathrm{t} / \mathrm{ha}$ Biochar $+100 \mathrm{~kg} / \mathrm{ha}$ NPK (BC2+NPK); Error bars represent standard deviation of the means 
Table 9 Effect of biochar, farmyard manure compost and inorganic fertilizer on the dry matter percentage of total N, P, K and $\mathrm{Ca}$ in the collard leaf after harvest

\begin{tabular}{lllll}
\hline Treatment & $\begin{array}{l}\text { Nitrogen } \\
\text { (\%) }\end{array}$ & $\begin{array}{l}\text { Potassium } \\
\text { (\%) }\end{array}$ & Calcium (\%) & $\begin{array}{l}\text { Phosphorus } \\
\text { (\%) }\end{array}$ \\
\hline $\mathrm{CTRL}$ & $0.66 \mathrm{e}$ & $0.94 \mathrm{e}$ & $1.32 \mathrm{e}$ & $0.38 \mathrm{~d}$ \\
$\mathrm{CM}$ & $1.18 \mathrm{bc}$ & $2.67 \mathrm{bc}$ & $3.56 \mathrm{~cd}$ & 0.91 \\
$\mathrm{NPK}$ & $0.72 \mathrm{e}$ & $1.83 \mathrm{~d}$ & $1.55 \mathrm{e}$ & $0.64 \mathrm{~cd}$ \\
$\mathrm{BC1}$ & $0.82 \mathrm{de}$ & $2.40 \mathrm{~cd}$ & $3.34 \mathrm{~d}$ & $0.74 \mathrm{bcd}$ \\
$\mathrm{BC2}$ & $0.91 \mathrm{de}$ & $2.87 \mathrm{abc}$ & $4.10 \mathrm{bc}$ & $1.17 \mathrm{ab}$ \\
$\mathrm{BC1}+\mathrm{CM}$ & $1.88 \mathrm{a}$ & $3.30 \mathrm{ab}$ & $4.34 \mathrm{~b}$ & $1.27 \mathrm{ab}$ \\
$\mathrm{BC2}+\mathrm{CM}$ & $2.01 \mathrm{a}$ & $3.51 \mathrm{a}$ & $4.99 \mathrm{a}$ & $1.41 \mathrm{a}$ \\
$\mathrm{BC1}+\mathrm{NPK}$ & $1.04 \mathrm{~cd}$ & $3.16 \mathrm{abc}$ & $3.69 \mathrm{~cd}$ & $0.81 \mathrm{abc}$ \\
$\mathrm{BC2}+\mathrm{NPK}$ & $1.35 \mathrm{~b}$ & $3.12 \mathrm{abc}$ & $3.98 \mathrm{bc}$ & $1.06 \mathrm{bcd}$ \\
$\mathrm{Significant}{ }^{\mathrm{X}}$ & $* * *$ & $* *$ & $* * *$ & $* *$ \\
SED $^{Y}$ & 0.97 & 0.19 & 0.15 & 0.13 \\
\hline
\end{tabular}

Significant ${ }^{X}$ and $\mathrm{SED}^{Y}$ effects were obtained from one-way analysis of variance: ******ignificant at $P<0.01$, and $P<0.001$, respectively. See Table 2 for a description of the treatments; Means followed by the same letter in each column are not significantly different at $p \leq 0.05$ using Tukey HSD

environment to the atmosphere for 1000 years and more (Lu et al. 2020; Hardy et al. 2017). The high available phosphorus and nitrogen in the combined biochar with compost and/NPK addition plots signified that there was a lot of excess nutrients which was not exhausted during the direct effects as compared to the solely residual compost and NPK plots as reported by Frimpong et al. (2020). The increase of the $\mathrm{N}$ content could probably assign to the residual $\mathrm{NH}_{4}{ }^{+}$absorbed on the biochar surface from the previously applied compost and the NPK, causing the slow release of $\mathrm{N}$ into the soil $\mathrm{N}$ pool (Zheng et al. 2013; Bai et al. 2015).

The biochar plots seem to improve the exchangeable cations exception for the surprising decrease of the sodium content. The increase of the potassium content was the result of the gradual leaching of the $\mathrm{K}^{+}$from the residual biochar into the soil environment. Immediately biochar is amended to the soil, there is a gradual increase of the potassium content in the soil due to the dissolution of potassium oxides from the biochar ash as reported by Hardy et al. (2017). The increase of the magnesium and the calcium content were ascribable to the gradual mineralization of the residual biochar, causing the release of the non-volatilized nutrients cations (Hailegnaw et al. 2019). Surprisingly, the residual biochar plot decreased the sodium content of the soil by increasing the sodium adsorption in the soil onto its biochar surface (Akhtar et al. 2015).

The residual effects of co-applied biochar with compost and NPK resulted in the enhancement of the soil physicochemical environment to elevate collard plant growth and biomass as the result of the excess nutrient which was not exhausted during the direct effects as reported by Frimpong et al. (2020) and Akhtar et al. (2015). Increasing crop yield and performance due to residual biochar effects have also been reported for crops including rice (Rizwan et al. 2018) and wheat (Akhtar et al. 2015). According to Akhtar et al. (2015), biochar increased wheat yield under salt stress and attributed it to the ability of the biochar to suppress the negative impact of salt on the vegetative growth and yield components whiles Frimpong et al. (2020), concluded that the increase of crop yield in biochar amended soil is due to the enhancement of the reproductive efficiency by the biochar. Also, the high nutrients composition of the collard leaves in the biochar amended soil could probably assigned to the excess nutrient which was not exhausted during the direct effects enhances the bioavailability of the soil nutrient for plant uptake (Nigussie et al. 2012; Agegnehu et al. 2016).

\section{Conclusion}

In this study, we demonstrated that the residual effect of combined application of biochar with compost and/ NPK enhanced the soil physicochemical properties such as soil $\mathrm{pH}$, total organic carbon, soil available phosphorus, total nitrogen etc., collard plant biomass and a nutritional constituent as compared to the residual effect of NPK and compost.

\section{Acknowledgements}

The authors thank African Center of Excellence in Agroecology and Livelihood System for their financial support and encouragement.

\section{Authors' contributions}

SOA and JB designed the research, perform the laboratory works, analyzed the data, wrote the manuscript and revised the drafted manuscript. GKM contributed to the collection of the field data and analyzed the data. All authors read and approved the final manuscript.

Funding

Not applicable.

\section{Availability of data and materials}

All data generated or analyzed during this study are included in this manuscript.

\section{Declarations}

Ethics approval and consent to participate Not applicable.

\section{Competing interests}

The authors declare that they have no competing interests.

Consent for publication

Not applicable. 


\section{Author details}

${ }^{1}$ African Center of Excellence in Agroecology and Livelihood System, Faculty of Agriculture, Uganda, Martyrs University, Kampala, Uganda. ${ }^{2}$ Faculty of Agriculture, Uganda Martyrs University, Kampala, Uganda.

Received: 22 March 2021 Accepted: 11 May 2021

Published online: 14 July 2021

\section{References}

Agegnehu G, Nelson PN, Bird MI (2016) Crop yield, plant nutrient uptake and soil physicochemical properties under organic soil amendments and nitrogen fertilization on Nitisols. Soil Tillage Res 1(160):1-3

Akhtar SS, Andersen MN, Liu F (2015) Residual effects of biochar on improving growth, physiology and yield of wheat under salt stress. Agric Water Manag 158:61-68

Al-Wabel MI, Hussain Q, Usman AR, Ahmad M, Abduljabbar A, Sallam AS, Ok YS (2018) Impact of biochar properties on soil conditions and agricultural sustainability: a review. Land Degrad Dev 29(7):2124-2161

Anderson JM, Ingram JS (1993) A handbook of methods. CAB International, Wallingford, Oxfordshire, p 221

Antonious GF, Turley ET, Hill RR, Snyder JC (2014) Chicken manure enhanced yield and quality of field-grown kale and collard greens. J Environ Sci Health B 49(4):299-304

Bai SH, Reverchon F, Xu CY, Xu Z, Blumfield TJ, Zhao H, Van Zwieten L, Wallace HM (2015) Wood biochar increases nitrogen retention in field settings mainly through abiotic processes. Soil Biol Biochem 90:232-240

Barros Al, de Oliveira AP, de Magalhães MR, Villa RD (2012) Determination of sodium and potassium in biodiesel by flame atomic emission spectrometry, with dissolution in ethanol as a single sample preparation step. Fuel 93:381-384

Blanco-Canqui H (2017) Biochar and soil physical properties. Soil Sci Soc Am J $81(4): 687-711$

Chen HX, Du ZL, Guo W, Zhang QZ (2011) Effects of biochar amendment on cropland soil bulk density, cation exchange capacity, and particulate organic matter content in the North China Plain. Ying Yong Sheng Tai Xue Bao J Appl Ecol 22(11):2930-2934

Choudhary AK, Thakur SK, Suri VK (2013) Technology transfer model on integrated nutrient management technology for sustainable crop production in high-value cash crops and vegetables in northwestern Himalayas. Commun Soil Sci Plant Anal 44(11):1684-1699

Ding Y, Liu Y, Liu S, Li Z, Tan X, Huang X, Zeng G, Zhou L, Zheng B (2016) Biochar to improve soil fertility. A review. Agron Sustain Dev 36(2):1-8

El-Naggar A, Lee SS, Rinklebe J, Farooq M, Song H, Sarmah AK, Zimmerman AR, Ahmad M, Shaheen SM, Ok YS (2019) Biochar application to low fertility soils: a review of current status, and future prospects. Geoderma 337:536-554

Enders A, Hanley K, Whitman T, Joseph S, Lehmann J (2012) Characterization of biochars to evaluate recalcitrance and agronomic performance. Bioresour Technol. 114:644-653

Frimpong KA, Phares CA, Boateng I, Abban-Baidoo E, Apuri L (2020) One-time application of biochar influenced crop yield across three cropping cycles on tropical sandy loam soil in Ghana. Heliyon. 7(2):e06267

Glaser B, Birk JJ (2012) State of the scientific knowledge on properties and genesis of Anthropogenic Dark Earths in Central Amazonia (terra preta de Índio). Geochim Cosmochim Acta 82:39-51

Hailegnaw NS, Mercl F, Pračke K, Száková J, Tlustoš P (2019) Mutual relationships of biochar and soil pH, CEC, and exchangeable base cations in a model laboratory experiment. J Soils Sediments 19(5):2405-2416

Hardy B, Cornelis JT, Houben D, Leifeld J, Lambert R, Dufey JE (2017) Evaluation of the long-term effect of biochar on properties of temperate agricultural soil at pre-industrial charcoal kiln sites in Wallonia, Belgium. Eur J Soil Sci 68(1):80-89

Jeffery S, Abalos D, Prodana M, Bastos AC, Van Groenigen JW, Hungate BA, Verheijen F (2017) Biochar boosts tropical but not temperate crop yields. Environ Res Lett 12(5):053001

Jien SH, Wang CS (2013) Effects of biochar on soil properties and erosion potential in a highly weathered soil. CATENA 110:225-233
Laird DA, Fleming P, Davis DD, Horton R, Wang B, Karlen DL (2010) Impact of biochar amendments on the quality of a typical Midwestern agricultural soil. Geoderma 158(3-4):443-449

Lehmann J, Joseph S, editors (2015) Biochar for environmental management: science, technology and implementation. Routledge

Lehmann J, Rillig MC, Thies J, Masiello CA, Hockaday WC, Crowley D (2011) Biochar effects on soil biota-a review. Soil Biol Biochem 43(9):1812-1836

Liu J, Schulz H, Brandl S, Miehtke H, Huwe B, Glaser B (2012) Short-term effect of biochar and compost on soil fertility and water status of a Dystric Cambisol in NE Germany under field conditions. J Plant Nutr Soil Sci 175(5):698-707

Lu H, Bian R, Xia X, Cheng K, Liu X, Liu Y, Wang P, Li Z, Zheng J, Zhang X, Li L (2020) Legacy of soil health improvement with carbon increase following one time amendment of biochar in a paddy soil_ - a rice farm trial. Geoderma 376:114567

McLaurin W, Reeves W (re 2009) How to convert an inorganic fertilizer recommendation to an organic one. University of Georgia Cooperative Extension, Athens, GA

Mensah AK, Frimpong KA (2018) Biochar and/or compost applications improve soil properties, growth, and yield of maize grown in acidic rainforest and coastal savannah soils in Ghana. Int J Agron 2018:1-8

Neugart S, Baldermann S, Ngwene B, Wesonga J, Schreiner M (2017) Indigenous leafy vegetables of Eastern Africa-a source of extraordinary secondary plant metabolites. Food Res Int 100:411-422

Nguyen TT, Wallace HM, Xu CY, Zwieten LV, Weng ZH, Xu Z, Che R, Tahmasbian I, Hu HW, Bai SH (2018) The effects of short term, long term and reapplication of biochar on soil bacteria. Sci Total Environ 636:142-151

Nielsen S, Joseph S, Ye J, Chia C, Munroe P, van Zwieten L, Thomas T (2018) Crop-season and residual effects of sequentially applied mineral enhanced biochar and $\mathrm{N}$ fertiliser on crop yield, soil chemistry and microbial communities. Agr Ecosyst Environ 255:52-61

Nigussie A, Kissi E, Misganaw M (2012) Effect of biochar application on soil properties and nutrient uptake of lettuces (Lactuca sativa) grown in chromium polluted soils.

Novak JM, Busscher WJ, Laird DL, Ahmedna M, Watts DW, Niandou MA (2009) Impact of biochar amendment on fertility of a southeastern coastal plain soil. Soil Sci 174(2):105-112

Regalado RG, Cruz JC (2016) Soil pH and nutrient (nitrogen, phosphorus and potassium) analyzer using colorimetry. In: 2016 IEEE Region 10 Conference (TENCON) (pp. 2387-2391). IEEE.

Rizwan M, Ali S, Abbas T, Adrees M, Zia-ur-Rehman M, Ibrahim M, Abbas F, Qayyum MF, Nawaz R (2018) Residual effects of biochar on growth, photosynthesis and cadmium uptake in rice (Oryza sativa L.) under Cd stress with different water conditions. J Environ Manage 206:676-683

Rhoades JD (1982) Cation exchange capacity. In: Page AL (ed) Methods of soil analysis. Part 2: chemical and microbiological properties (2nd edn), Agronomy, vol 9, pp 149-157

Ronsse F, Van Hecke S, Dickinson D, Prins W (2013) Production and characterization of slow pyrolysis biochar: influence of feedstock type and pyrolysis conditions. GCB Bioenergy 5(2):104-115

Sáez-Plaza P, Navas MJ, Wybraniec S, Michałowski T, Asuero AG (2013) An overview of the Kjeldahl method of nitrogen determination. Part II. Sample preparation, working scale, instrumental finish, and quality control. Crit Rev Anal Chem 43(4):224-272

Sahrawat KL, Jones MP, Diatta S (1997) Extractable phosphorus and rice yield in an Ultisol of the humid forest zone in West Africa. Commun Soil Sci Plant Anal 28(9-10):711-716

Sánchez-Monedero MA, Cayuela ML, Sánchez-García M, Vandecasteele B, D’Hose T, López G, Martínez-Gaitán C, Kuikman PJ, Sinicco T, Mondini C (2019) Agronomic evaluation of biochar, compost and biochar-blended compost across different cropping systems: perspective from the European project FERTIPLUS. Agronomy 9(5):225

Schulte EE, Hoskins B (1995) Recommended soil organic matter tests. Recommended soil testing procedures for the North Eastern USA. Northeastern Reg Publ 493:52-60

Selim MM (2020) Introduction to the integrated nutrient management strategies and their contribution to yield and soil properties. Int J Agron. 2020:1-14

Sohi SP, Krull E, Lopez-Capel E, Bol R (2010) A review of biochar and its use and function in soil. Adv Agron 105:47-82 
Tang J, Zhang L, Zhang J, Ren L, Zhou Y, Zheng Y, Luo L, Yang Y, Huang H, Chen A (2020) Physicochemical features, metal availability and enzyme activity in heavy metal-polluted soil remediated by biochar and compost. Sci Total Environ 701:134751

van der Wurff AW, Fuchs JG, Raviv M, Termorshuizen A (2016) Handbook for composting and compost use in organic horticulture. BioGreenhouse. Verheijen F, Jeffery S, Bastos AC, Van der Velde M, Diafas I (2010) Biochar application to soils. A critical scientific review of effects on soil properties, processes, and functions. Eur 24099:162

Wisnubroto El, Utomo WH, Soelistyari HT (2017) Biochar as a carrier for nitrogen plant nutrition the release of nitrogen from biochar enriched with ammonium sulfate and nitrate acid. Int J Appl Eng Res 12(6):1035-1042

Xu HJ, Wang XH, Li H, Yao HY, Su JQ, Zhu YG (2014) Biochar impacts soil microbial community composition and nitrogen cycling in an acidic soil planted with rape. Environ Sci Technol 48(16):9391-9399
Yuan H, LuT, Wang Y, Huang H, Chen Y (2014) Influence of pyrolysis temperature and holding time on properties of biochar derived from medicinal herb (radix isatidis) residue and its effect on soil $\mathrm{CO}_{2}$ emission. J Anal Appl Pyrol 110:277-284

Yuan JH, Xu RK, Zhang H (2011a) The forms of alkalis in the biochar produced from crop residues at different temperatures. Biores Technol 102(3):3488-3497

Zheng H, Wang Z, Deng X, Herbert S, Xing B (2013) Impacts of adding biochar on nitrogen retention and bioavailability in agricultural soil. Geoderma 206:32-39

\section{Publisher's Note}

Springer Nature remains neutral with regard to jurisdictional claims in published maps and institutional affiliations.

\section{Submit your manuscript to a SpringerOpen ${ }^{\circ}$ journal and benefit from:}

- Convenient online submission

- Rigorous peer review

- Open access: articles freely available online

- High visibility within the field

- Retaining the copyright to your article

Submit your next manuscript at $\boldsymbol{\nabla}$ springeropen.com 